\title{
THE JURY AND THE EXCLUSIONARY RULES OF EVIDENCE
}

\author{
EDMUND M. MORgaN* \\ "The English law of evidence, which is the child of the jury." \\ James Bradley Thayer \\ "The fallacy that whatever is morally convincing and whatever rea- \\ sonable beings would form their judgments and act upon, may \\ be submitted to a jury." \\ Mr. Justice Coleridge
}

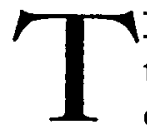

HE Anglo-Saxon trial by ordeal and trial by compurgation and the Anglo-Norman trial by battle were essentially adversary proceedings, conducted under public supervision, by which the litigants appealed to the Deity for a decision. The institution of trial by inquest or recognition, from which trial by jury soon evolved, not only substituted a resort to reason for reliance on superstition, but also removed the proceeding completely from the control of the adversaries. It compelled them to submit to "the test of what a set of strangers might say, witnesses selected by a public officer."I This set of strangers was originally an investigative body chosen for the supposed capacity of its members to answer the disputed question without help from the court and without aid or hindrance from the parties. The parties were permitted to state what they respectively asserted to be the facts. Later they secured the privilege of presenting additional information through witnesses. By the middle of the Sixteenth Century this had become a common practice. The jury came to rely more and more upon what the parties presented in open court and less and less upon what its individual members knew or learned from other sources, so that at the beginning of the Seventeenth Century Coke could truly say that "most commonly juries are led by deposition of witnesses." Less than a century and a half later it had become established that the jury must base its verdict not upon the private knowledge or information of its members but solely upon the evidence given in open court. ${ }^{3}$ And this evidence was furnished

* Acting Dean, Harvard University Law School.

I Thayer, Preliminary Treatise on Evidence 56 (1898).

$=$ Coke, Third Institute 163 (ed. of 1817 ).

${ }_{3}^{3}$ Wigmore, Evidence $\$$ r364 (2d. ed. I923). 
by the adversaries. Trial by jury had been transformed from an investigative or inquisitorial to an adversary proceeding. Thus, the parties furnish and control the material upon which the modern jury is required to exercise its rational processes, just as in trial by compurgation, ordeal and battle the parties furnished and controlled the material through which the Divine judgment was made manifest.

In the operation of any system which undertakes to settle disputed questions of fact by rational methods, there will inevitably be evolved rules regulating the scope of permissible inquiry, the qualifications of the persons to be heard and the kind of information to be gathered and considered. Among the factors which will most powerfully influence the character and content of these rules one would expect to find not only the competence or lack of competence of the tribunal upon which is imposed the task of resolving the dispute, but also the means by which and the extent to which sources of information are made available to it. Since the adversary feature of our system is quite as distinctive as is its use of a jury, it may be well not to accept without scrutiny the oftrepeated statement that the jury is responsible for the origin and persistence of our law of evidence. Particularly is caution needed when declarations like that of Lord Coleridge in Wright v. Doe d. Tatham ${ }^{4}$ are taken to mean that the jury is the sole or chief cause of all those rules which require the rejection of logically relevant evidence.

Foremost among the exclusionary rules of the common law are those which render certain persons incompetent to testify because of mental deficiency, religion, interest, marital relationship and infamy. While it is too obvious for comment that these disqualifications had and have no basis in the adversary character of the proceeding, it also seems clear that they are in no appreciable degree connected in origin or experience with any supposed incapacity of a jury to evaluate the testimony of the disqualified persons. Once the concept of mental derangement as a Divine visitation was abandoned, the test of intellectual capacity to testify became the capacity to perceive, remember and relate intelligently-a test applicable to all rational investigations by any body, skilled or unskilled. Similarly the disqualification of mental immaturity operated only where it negatived that capacity, except in so far as it revealed inability to take an oath understandingly. Religious qualifications also were insisted upon only to the extent to which they affected ability and willingness to take a binding oath. The oath-requirement was rigidly enforced in the forms of trial which preceded the jury; and there is no reason to suppose that

${ }_{4} 5$ Cl. \& Fin. 670, 690 (H.L. I838), quoted supra. 
its retention was due to any mistrust of the jury as a fact-finding tribunal. The disqualification for interest, whatever its origin, is not peculiar to the jury system, for, as Mr. Wigmore says, it "is found long established, by adoption from the Roman law, in the ecclesiastical rules as practised in England."' Infamy by conviction of crime, likewise, created incompetence under other systems, and it has been suggested that there is something generic and universal in the origin of this disqualification. In the Roman and ecclesiastical law, too, is the concept that lies at the root of the rule forbidding one spouse to be a witness for or against the other. ${ }^{6}$ And the justification for such remnants of it as still persist, is put upon grounds of policy which have no relation to the jury. For the harm done, therefore, by the exclusion of relevant material on account of the common law rules governing competency of witnesses, the jury system cannot be blamed.

The same is true as to that large body of evidence made unavailable through the exercise of the common law privileges. Each rule of privilege concededly authorizes the suppression of the truth and prevents the trier of fact, whether judge or jury, from hearing pertinent testimony easy to value by even the most unsophisticated. Almost every one of them rests upon the gratuitous assumption that it furthers a supposedly sound social policy. The privilege of one spouse to refuse to testify against the other and to prevent the other from testifying against him has its basis in the judicial desire to foster marital harmony. A similar policy accounts for the privilege of a spouse that confidential communications between husband and wife be not disclosed. The privilege against self-crimination has a separate and distinct history, probably coming into the common law as the result of resistance to ecclesiastical heresy hunts; ${ }^{7}$ neither in origin nor in subsequent history has it any connection with any assumed or demonstrated inadequacy of the jury to handle the criminating material. The privilege of a client that confidential communications between himself and his attorney shall not be disclosed began as the privilege of the attorney that he should not be compelled to violate his honor as a gentleman by committing a breach of confidence. Its continued existence is sought to be justified for reasons builded upon the postulate that skilled assistance in the presentation of litigated cases is essential. If this is sound, it is largely because our system is adversary from the inception of an action to its termination. No doubt the existence of a mass of rules as to the admissibility of evidence adds to the complexities of litigation, and

$s$ I Wigmore, op. cit. supra note 3 , at $\$ 575$, p. 989 .

${ }^{6} I d$. at $\$ 600$.

${ }^{7} 4$ id. at $\$ 2250$. 
thus makes for the need of expert assistance. ${ }^{8}$ But if the judge were under the duty of excluding all objectionable evidence, aid of counsel would be less imperative. However, under the adversary system the judge's duty in this respect is merely to rule upon objections interposed by the adversary. And much inadmissible evidence is made so for reasons that would be equally applicable had jury trial never been instituted. Certainly no one could seriously contend that state secrets and certain portions of official documents are subject to exclusion because the jury is a part of the trial tribunal.9 Consequently if our law of evidence had confined its rejection of relevant evidence to that coming from incompetent witnesses and that falling within the scope of the privileges, there could have been little, if any, foundation for imputing its origin to the jury.

The rules which conditionally prefer one sort of evidence or one class of witnesses over another do not in terms absolutely exclude relevant evidence, but they sometimes reach that result when the conditions upon which the preference may be avoided are not fulfilled by the proponent. The requirement that a documentary original must be produced as evidence of its content has its roots in the ancient substantive law, which identified the legal consequences of a document with the document itself. The method of trial, where the authenticity of the writing was in dispute, was by deed witnesses before the court, and not by jury. As trial by jury gradually displaced trial by documents, the requirement of profert in pleading made mandatory the production of the original in court. So long as pleadings were oral, there was in effect no difference between its production and what, under later practice, would have been its introduction in evidence. By just what process, when oral pleadings disappeared, the principle which had been enforced by profert made itself manifest in a rule of evidence is not quite clear. But by the early Eighteenth Century, it had happened. Chief Baron Gilbert's explanation is, generally

that a man must have the utmost evidence the nature of the fact is capable of; .... less evidence doth create but opinion and surmise, and does not leave a man the entire satisfaction that arises from demonstration; for if it be plainly seen in the nature of the

\footnotetext{
${ }^{8}$ No doubt, too, the division of functions between judge and jury particularly as applied to questions preliminary to the admissibility of evidence increases the complexities of the trial. See Maguire and Epstein, Preliminary Questions of Fact in Determining Admissibility of Evidence, 40 Harv. L. Rev. 392 (1927); Morgan, Functions of Judge and Jury in the Determination of Preliminary Questions of Fact, 43 Harv. L. Rev. I65 (I929). The presence of the jury obviously creates many problems of procedure throughout the trial.
}

9 An examination of the various subjects of privilege treated by Dean Wigmore in $\$ \S 2210$ to 2224 will disclose no influence of the jury system upon the rulings. 
transaction that there is some more evidence that doth not appear, the very not producing it is a presumption that it would have detected something more than appears already .....

\section{Specifically he says:}

But deeds are only private evidences . . . . and therefore they must be produced in evidence; for the law requires the best evidence that the nature of the thing is capable of, and the deed is much better evidence than the copy of it, for the rasure and interlineation that might vacate the deed, might appear in the deed itself, and the very offering a copy carries a presumption, as if the original were defective . . . II

Though this reasoning leaves much to be desired, and the danger of honest mistake in recollection or transcription is equally important, a combination of these considerations furnishes a justification for the retention of the doctrine; and this notwithstanding the fact that it came into our law in the historical evolution of quite a different concept.

The common law preference for the testimony of attesting witnesses likewise finds its origin in days long antedating the jury; they are the successors of "that very ancient class of transaction or business witnesses, running far back into the old Germanic law, who were once the only sort of witnesses that could be compelled to come before a court." 12 Persisting through the evolution of trial by jury, this preference was sought to be justified on such specious reasoning as that the parties had agreed or were supposed to have agreed that the writing should not be given in evidence without calling the attesting witness, or that the opponent is entitled to have him produced for cross-examination concerning the circumstances of the execution of the instrument. There is not the slightest suggestion, it will be noted, that the rule is in any degree attributable to the existence of the jury. As in Chief Baron Gilbert's exposition of the preference for the original document, here too the central theme is the obligation of the proponent to produce the best he has, so that it may be scrutinized by the adversary and its weaknesses exposed to the trier. Indeed Mr. Wigmore believes that whatever justification such a rule may have is that it tends to insure "a supply of trustworthy testimony which otherwise the partisan interests of either side might fail to furnish." In other words, these rules of preference are merely a salutary modification of the adversary's control over the course of litigation.

The so-called opinion rule, in so far as it relates to the conditions upon

to Gilbert, Evidence 4 (ed. of 1760 ). (Written before I $_{726 .)}$

xI Id. at 96 .

${ }^{13}$ Thayer, op. cit. supra note I, at 502.

${ }_{3} 2$ Wigmore, op. cit. supra note 3 , at $\S$ I286, p. 937. 
which expert testimony is received, can hardly be said to operate to exclude pertinent evidence. The reception of expert aid by the court is found in the Year Books and other early reports. Its use as an aid to the jury was early established. The silly refinements engrafted upon it in some of our states are quite as much a reflection upon the intelligence of judges as an imputation of incapacity to jurors. They do not obtain in England; and with us they are usually applied to trials by the court as well as to trials by jury. The rule excluding lay opinion, however, often results in depriving court and jury of valuable information. Of course, no intelligent trier of fact needs the aid of an unskilled witness in drawing inferences from evidence properly in the case. Equally true is it that the principle underlying the hearsay rule makes unacceptable the beliefs, impressions and deductions of a lay witness concerning material matter learned from others. But in many instances testimony in the form of beliefs, impressions and deductions is merely an expression of relevant personal experiences of the witness. To reject it is to insist upon form of statement at the expense of substance, and to accept a doctrine which originated half a century after jury trial in its present form had come to maturity, a doctrine, moreover, which has not "obtained orthodox standing in the original home of our jurisprudence." I4 It can, therefore, safely be asserted that there is no objectionable feature of the opinion rule which considerations looking to the protection of the jury can be relied upon to explain or justify.

The history of the hearsay rule, the reasons assigned for its application and the judicial explanations for limitations upon it may throw light upon the causes for its creation and persistence. There can be no question that during the first few centuries of the existence of the jury, it could properly base its decision on information received otherwise than in open court. It was very early recognized that jurors might properly answer as the result of data obtained "through the words of their fathers and through such words of other persons whom they are bound to trust as worthy." 15 During the Sixteenth Century hearsay from witnesses was freely received. Towards the end of that century there were numerous objections raised, but many, if not most, of them went to the weight of hearsay rather than to its admissibility; and there was discussion looking toward the establishment of something akin to the numerical system of the civil law. By the middle of the Seventeenth Century the objections

$\mathrm{I}_{4} 4 i d$. at $\S \mathrm{x}_{917}$, p. ro8.

2s Brunner, The Origin of Jury Courts $427,45^{2}$ (1872), as quoted in 3 Wigmore, op. cit. supra note 3 , at $\S \mathrm{I} 364$, p. Io. 
grew in number and force, and in its last quarter became effective to cause the rejection of hearsay in the usual case, although it continued to be received in corroboration of other evidence at least during the first quarter of the Eighteenth Century. The grounds of rejection are thus put by Chief Baron Gilbert:

The attestation of the witness must be to what he knows, not to that only which he hath heard, for mere hearsay is no evidence; for it is his knowledge which must direct the Court and Jury in the judgment of the fact, and not his mere credulity. .... Besides though a person testify to what he hath heard upon oath, yet the person who spake it was not upon oath; and if a man had been in Court and said the same thing and had not sworn it, he had not been believed in a court of justice. $\ldots .^{16}$

But as early as 1668 a hearsay sworn statement was rejected because "the other party could not cross-examine the party sworn, which is the common course"; $; 7$ and in 1696 sworn depositions of a witness since deceased were excluded by the King's Bench:

The Court sent the puisne judge to confer with the Justices of the Common Pleas; who returning, the Chief Justice declared, that it was the opinion of both Courts that these depositions should not be given in evidence, the defendant not being present when they were taken before the mayor, and so had lost the benefit of a cross-examination. ${ }^{88}$

Before the opening of the Eighteenth Century, then, we find expressed the two reasons still most frequently put forward for the rejection of hearsay-lack of oath and lack of opportunity for cross-examination. It is now established that sworn hearsay is inadmissible; it is very probably true that cross-examined hearsay not given under oath is likewise subject to exclusion; and there is some authority for the proposition that hearsay given under oath and subject to cross-examination other than in a formal proceeding should be rejected.9 In the modern cases the emphasis is so heavily placed upon the opportunity to cross-examine that Mr. Wigmore states the gist of the hearsay rule to be that it "prohibits the use of a person's assertion as equivalent to testimony to the fact asserted unless the asserter is brought to testify in court on the stand, where he may be probed and cross-examined as to the grounds of his assertion and his qualifications to make it." 20

In so far as the oath or its equivalent is a prerequisite to admissibility of testimony, neither its history nor its employment in modern litigation.

${ }^{16}$ Gilbert, op. cit. supra note ro, at 152.

${ }^{17} 2$ Rolle's Abr. 679, pl. 9 (r668).

${ }^{18}$ Rex v. Paine, 5 Mod. 163 , I65 (I6g6).

19 See Deering v. Schreyer, 88 App. Div. 457,85 N.Y. S. 275 (1903).

${ }^{20} 3$ Wigmore, op. cit. supra note 3 , at $\S \mathrm{I} 364$, p. 9 . 
furnishes any basis for any reasonable contention that it is imposed for the peculiar benefit of the jury. It is merely a means of assuring the trier or investigator that the witness is under a realization of his obligation to tell the truth. As to cross-examination, there can be no doubt that when properly used, it is a most effective instrument for the discovery of the facts so far as they are within the ability of the witness to disclose. And it might well be argued that in view of the defective powers of perception, memory and narration of the ordinary witness and his weaknesses or worse as regards veracity, the unskilled jury ought not to be permitted to rely upon his uncross-examined testimony. If such were the rule, there could then be little doubt of its intimate connection with the jury, and there would be little reason for applying it in trials by the judge. But it is not, and never has been the rule. It has never been suggested that the adversary is under any obligation to cross-examine any witness; and it is equally well settled that the judge is under no duty to do so. Indeed, in most American jurisdictions, cross-examination by the judge is a precarious proceeding, for he may commit the awful sin of indicating to the jury his opinion upon the facts. ${ }^{2 x}$ Since no official cross-examiner is provided, the jury may have to come to its decision upon testimony which has not been purified (or poisoned) by cross-examination. But the adversary cannot be deprived of his right to cross-examine. There are a few English cases in chancery which admit testimony given under oath in open court against a party who without fault of his own or of his adversary has been prevented from cross-examining. The accepted doctrine in this country, however, requires the court on motion of the adversary to strike direct testimony where without his fault or acquiescence he has not been given the opportunity to cross-examine. ${ }^{22}$ And it seems a reasonable deduction from the authorities that this right of a party could not be denied merely because of a searching cross-examination conducted by the judge. Furthermore, denial of the right to cross-examine is equally fatal in a case tried without a jury, whether it be one in which the jury is waived or one in which there is no right to trial by jury. ${ }^{23}$ It is, therefore, suggested that had the Normans abolished the Anglo-Saxon forms of trial

as This indicates the extent to which our courts have gone in preventing the jury from receiving aid to which the adversary objects.

2 See e.g., People v. Cole, 43 N.Y. 508 (187r).

${ }^{23}$ It is true that the court receives uncross-examined sworn testimony in interlocutory proceedings, and there is a conflict as to the applicability of the rules of evidence to hearings by the judge upon matters preliminary to the admissibility of evidence. See Maguire and Epstein, Rules of Evidence in Preliminary Controversies as to Admissibility, 36 Yale L.J. IIOI (I927). 
and replaced them with trial by any body of skilled triers, such as judges or other expert investigators, and had the parties succeeded, by the process of securing and enlarging the privilege of submitting evidence, in changing the trial from an investigative to an adversary proceeding, a rule forbidding the reception of hearsay would have developed. The right of a party to cross-examine is an essential element of an adversary system; it is not a necessary concomitant of trial by jury. It may be true that nonjury systems have not created a hearsay rule; but that has no compelling significance so long as they have not adopted an adversary theory of litigation. And it is little more than speculation to intimate that a nonjury substitute for the earlier forms of trial in England would not have evolved into an adversary proceeding. Certainly there is little or nothing in the reports of judicial proceedings to justify, much less to force, the inference that the jury is responsible for its own transformation from an investigative body acting upon information gathered from all available and reliable sources into a tribunal compelled to rely principally, if not entirely, upon materials furnished by the adversaries.

In judicial discussions dealing with accepted or proposed exceptions to the hearsay rule there is much to be found indicating a distrust of the jury's capacity to handle such hearsay as does not carry some warranty of verity. ${ }^{24}$ It must, therefore, be conceded that in framing some parts of the law governing hearsay the courts have been consciously influenced by the fact that the tribunal to which the evidence is addressed is the jury. This is not so manifest in the earlier decisions, wherein the chief argument for admissibility is necessity; the witness could have testified if present; since he is dead, his hearsay statement is the best evidence available. But then the exceptions were few; now they are numerous. An examination of Mr. Wigmore's treatise will reveal at least eighteen different classes of hearsay for the reception of each of which respectable authority may be found. ${ }^{25}$ In most of these Mr. Wigmore finds some guaranty of trustworthiness; but in many of them it is tenuous even in general theory and practically non-existent in specific application. In fact the body of the

${ }^{24}$ But even so, if the hearsay is received without objection by the adversary the jury may by the majority view use it and base a verdict upon it. See Barlow v. Verrill, 183 Atl. 857 (N.H. 1936), annotated in I04 A.L.R. II30 (1936).

${ }^{25}$ Reported Testimony, Personal Admissions, Vicarious Admissions, Declarations against Interest, Official Written Statements, Business Entries, Subscribing Witnesses, Pedigree, Reputation, Ancient Documents, Declarations as to Boundaries, Dying Declarations, Declarations of Mental Condition, Spontaneous Declarations, Contemporaneous Declarations, Narratives of Testators, Voters' Statements, Commercial Lists, Learned Treatises; - these titles suggest the classes, though Mr. Wigmore does not classify Reported Testimony as hearsay. 
exceptions can be explained only as the resultant of conflicting considerations. Without going into detail, it will suffice to point out that the reception of admissions and the rejection of much reported testimony rest only upon the adversary theory of litigation. Extra-judicial statements of a party to the action are admitted against him although he is incompetent as a witness in the case ${ }^{26}$ and although he was without personal knowledge of the matter asserted and was expressing a self-serving deduction from inadmissible hearsay. ${ }^{27}$ On the other hand relevant testimony given in a prior action by a competent witness under oath and then cross-examined is rejected when offered against a party who had no opportunity to crossexamine the witness when so testifying. Moreover it is, by the orthodox rule, excluded even though the witness was actually cross-examined by the party against whom it is offered, if it could not be received against the party offering it. ${ }^{28}$ The doctrine of mutuality as applied here reflects the notion of fair play between antagonists. In most of the exceptions, however, the adversary theory is disregarded and the courts purport to find some circumstance which serves as a substitute for an oath and thus furnishes a so-called guaranty of trustworthiness. This usually means nothing more than that an ordinary man in the situation of the declarant would have desired to tell the truth, and, sometimes, merely that he would have had no motive to falsify. At times a court will disregard both the adversary and the trustworthiness theories and put the reception frankly upon the ground that the evidence is needed and hearsay is better than no evidence. ${ }^{29}$ Consequently it may be truly said that the jury is in part responsible for a portion of the law creating and governing exceptions to the hearsay rule, but certainly not for all of it.

Evidence which has only slight or remote probative value is ordinarily not worth the time and expense involved in presenting and considering it and should not be received by any trier, however great his powers of discrimination. In two classes of cases exclusion is particularly desirable when the trier is unskilled, namely, cases where this evidence will create an unjustifiable prejudice, and those where it will confuse the issues. Consequently, in such cases the courts are found basing their rulings of

${ }^{26}$ See e.g., Atchison, Topeka \& Santa Fe Railway Co. v. Potter, 60 Kan. 808, 58 Pac. 47 I (I899).

27 See Reed v. McCord, 160 N.Y. 330, 54 N.E. 737 (I899); Cady v. Doxtator, I93 Mich. I70, I59 N.W. I5I (I9I6); Kaiser v. United States, 60 F. (2d) 4Io (C.C.A. 8th I932); Mayhew v. Travelers' Protective Ass'n of America, 52 S.W. (2d) 29 (Mo.App. I932).

${ }^{28}$ See e.g., Metropolitan St.Ry.Co. v. Gumby, 99 Fed. 192 (C.C.A. $2 d$ I900).

${ }^{29}$ See e.g., Mr. Justice Green in Railing v. Commonwealth, IIo Pa. I00, I05 (1885), speaking of dying declarations. 
rejection upon the dangers to which reception would expose ordinary jurors. It often happens, however, that an item of testimony will have a highly and illegitimately prejudicial effect upon one issue and a substantial, legitimately logical value upon another. The court then, with an inconsistency born of necessity, assumes that the jury which has not sufficient capacity to make the necessary discriminations upon the first issue has the ability to perform the psychological feat of disregarding the item entirely upon the first issue and of confining its influence to the second issue. Nevertheless, it cannot be gainsaid that this group of exclusionary decisions owes its existence and persistence largely, though not entirely, to the jury.

But the jury cannot be charged with the slightest measure of responsibility for that most senseless of all evidential rules, the rule which forbids a party to impeach his own witness. In most matters of impeachment the courts attribute to the jury very remarkable intellectual powers. They assume that it can hear that the defendant has been convicted of prior felonies and not be at all influenced thereby in considering his guilt or innocence of the crime charged but will use this evidence only to aid in determining whether he told the truth on the witness stand. They assume also that it can be trusted to hear prior contradictory statements of the opponent's witness and to treat them as having no probative value upon the matter asserted but as bearing only upon the credibility of the witness. Consequently this prohibitory rule cannot be founded upon any distrust of the jury. It must have some other explanation.

It has been thought that it is derived from trial by compurgation or from the decisory oath of the Roman law..$^{30}$ That may be so, but it is not found in jury trial till toward the end of the Seventeenth Century. In two criminal trials in I68I the defendant was informed that when he called witnesses, he called them as witnesses to the truth; $;^{3 x}$ and in $I 700$ in a civil case Holt, C.J., refused to allow the plaintiff to discredit "a witness of his own calling." ${ }_{32}$ It will be remembered that these cases occurred at a time when in civil cases the parties had for a long time enjoyed the privilege of presenting evidence through witnesses and when in criminal cases the defendant had but recently secured it. The jury still could rely upon information which it had acquired elsewhere than in court. The witnesses whom the parties presented were of their own selection. Nothing was

${ }^{30}$ See 2 Wigmore, op. cit. supra note 3 , at $\$ 896$.

3r Fitzharris's Case, 8 How. St. Tr. 223, 369, 373 (I68I); Colledge's Case, 8 How. St. Tr. $549,636(\mathrm{r} 68 \mathrm{r})$.

32 Adams v. Arnold, I2 Mod. 375 (I700). 
more to be expected than the assumption that a party who exercised the privilege of presenting information through a witness must see to the reliability of his witness. The trial was taking on the aspect of a contest between the parties, largely under the control of the parties; the witnesses selected by the party were naturally regarded as his partisans, and not as witnesses of the court or of the jury. And when the trial became completely adversary in character the rule forbidding impeachment remained a logical concomitant of it, whether consciously affected by the analogy of compurgation or not. ${ }^{33}$

What then is the conclusion of the whole matter? Our exclusionary rules of evidence are the resultant of several factors. Ancient ideas as to the reliability of witnesses have had their influence. Judicial convictions that the privilege of suppressing the truth is essential to the fostering of certain socially desirable relationships and to the protection of the citizen from persecution have played a large part. The adversary theory of litigation is directly responsible for many of them; and judicial distrust of the jury for not a few. But the dictum of the great Thayer that the English law of evidence is "the child of the jury" 34 is, it is suggested with the greatest deference, not more than a half-truth..$^{35}$

33 This explanation is suggested in Ladd, Impeachment of One's Own Witness-New Developments, 4 Univ. Chi. L. Rev. 69 (1936).

34 Thayer, op. cit. supra note I, at 47 , quoted supra.

35 It is hoped that this little essay will incite some more learned writer to take issue with its thesis and demonstrate its certain faults and probable inaccuracies. If Judge Hinton were still with us, he would no doubt in his kindly but devastating manner make clear that, in so far as it is not a mere jousting at windmills, it is unsound. 